\title{
Extração de DNA a partir de sangue humano coagulado para aplicação nas técnicas de genotipagem de antígenos leucocitários humanos e de receptores semelhantes à imunoglobulina
}

\author{
DNA extraction from coagulated human blood for application in \\ genotyping techniques for human leukocyte antigen \\ and immunoglobulin-like receptors
}

\section{Daniela Maira Cardozoㄹ, Gláucia Andréia Guelsin ${ }^{1}$, Samaia Laface Clementino", Fabiano Cavalcante de Melo ${ }^{1}$, Marco Antônio Braga ${ }^{1}$, Cleonice de Souza ${ }^{2}$, Ricardo Alberto Moliterno ${ }^{1}$ e Jeane Eliete Laguila Visentainer ${ }^{1}$}

\begin{abstract}
RESUMO
O objetivo deste estudo foi padronizar uma metodologia de extração de DNA de alta qualidade a partir de amostras de sangue coagulado. Quarenta e oito amostras de sangue humano coagulado foram utilizadas para a extração de DNA pelo kit comercial EZ-DNA ${ }^{\circledR}$ (Biological Industries, Beit Haemek, Israel), pelo kit de coluna Neoscience ${ }^{\circledR}$ (One Lambda Inc., San Diego, CA) e pelo método modificado de salting out. Apenas o método de salting out foi capaz de extrair altas concentrações de DNA (média, 180ng/ $\mathrm{LL}$ ), as quais foram medidas pelo detector de fluorescência Qubit ${ }^{\circledR}$ (Invitrogen, USA). Este método permitiu a amplificação dos genes HLA (buman leukocyte antigens) pela tecnologia PCR-SSO (polymerase chain reaction - specific sequence of oligonucleotides) Luminex, a qual exige DNA de boa qualidade, e de genes KIR (killer cell immunoglobulin-like receptors) pela técnica made in house PCR-SSP (polymerase chain reaction-sequence specific of primers), a qual demanda uma concentração específica de DNA (10ng/ $\mu \mathrm{L})$. Concluímos que a técnica de salting out modificada foi muito eficiente, simples e rápida para a extração de DNA de amostras de sangue humano coagulado, com o objetivo de realizar a genotipagem de genes HLA e KIR.
\end{abstract}

Palavras-chaves: Extração de DNA. Sangue coagulado. Biologia molecular. Padronização.

\begin{abstract}
The objective of this study was to standardize a method for extracting high-quality DNA from samples of coagulated blood. Forty-eight samples of human coagulated blood were used for DNA extraction by means of the EZ-DNA ${ }^{\circledast}$ commercial kit (Biological Industries, Beit Haemek, Israel), the Neoscience ${ }^{\circledast}$ column kit (One Lambda Inc., San Diego, CA, USA) and a modified salting-out method. Only the salting-out method was able to extract high concentrations of DNA (mean, $180 \mathrm{ng} / \mu \mathrm{l}$ ), which were measured using the Qubit ${ }^{\circledR}$ fluorescence detector (Invitrogen, USA). This method enabled amplification of HLA (human leukocyte antigen) genes using the Luminex PCR-SSO (polymerase chain reaction - sequence-specific oligonucleotide) technology, which demands good quality DNA, and amplification of KIR (killer-cell immunoglobulin-like receptor) genes using an in-house PCR-SSP (polymerase chain reaction - sequence-specific primer) technique, which demands a specific concentration of DNA (10 ng/pl). We concluded that the modified salting-out technique was very efficient, simple and fast for DNA extraction from human coagulated blood samples, with the aim of genotyping the HLA and KIR genes.
\end{abstract}

Key-words: DNA extraction. Coagulated blood. Molecular biology. Standardization.

\footnotetext{
1. Laboratório de Imunogenética, Departamento de Análises Clínicas, Universidade Estadual de Maringá, Maringá, PR. 2. 15ª Regional de Maringá, Secretaria de Saúde do Estado do Paraná, Maringá, PR.

Apoio financeiro: PROAP-CAPES, UEM

Endereço de correspondência: Dra. Jeane Eliete Laguila Visentainer. Laboratório de Imunogenética/Dept ${ }^{0}$ de Análises Clínicas/UEM. Av. Colombo 5790, 87020-900 Maringá, PR.

Tel: 5544 3261-4864; Fax: 5544 3261-4931

e-mail: jelvisentainer@uem.br

Recebido para publicação em 18/05/2009

Aceito em 23/10/2009
}

Muitos testes genéticos envolvidos em estudos de doenças humanas necessitam da utilização do DNA genômico extraído de amostras de sangue. Normalmente, o DNA genômico é obtido a partir da separação da camada de células brancas (buffy-coat) ou do sangue total.

Frequentemente, ensaios genéticos envolvendo a reação em cadeia da polimerase (PCR) para a extração de DNA, utilizam amostras de sangue coletadas com anticoagulantes ${ }^{3}$. Com isso, é possível a separação de células e plasma do sangue 
por centrifugação e, portanto, a retirada da camada de células nucleadas.

No entanto, em muitos laboratórios, amostras de sangue coletadas para sorologia não utilizam anticoagulante e são descartadas, por serem inviáveis para os estudos genéticos, uma vez que a extração de DNA genômico destas amostras é dispendiosa e os resultados não são satisfatórios ${ }^{1}$.

Muitos métodos para o isolamento de DNA de amostras coaguladas foram descritos e alguns deles enfocam a obtenção de um DNA satisfatório para a PCR $^{6}$. Outras técnicas se preocupam com amostras de DNA de alta qualidade, porém são procedimentos demorados e bastante trabalhosos, envolvendo processos de homogeneização do coágulo ${ }^{2}$.

Com isso, uma técnica rápida e eficiente de extração de DNA de sangue coagulado se faz necessária, uma vez que materiais biológicos que podem ser utilizados para muitos estudos genéticos são descartados rotineiramente. Além disso, esta metodologia pode representar mais uma opção para a extração de DNA de amostras cujo anticoagulante foi ineficaz.

Portanto, o objetivo do presente trabalho foi padronizar uma metodologia para obtenção de altas concentrações de DNA com boa qualidade, a partir de amostras de sangue coagulado, para aplicação em estudos de marcadores moleculares.

\section{MATERIAL E MÉTODOS}

Este projeto foi analisado e aprovado pelo Comitê de Ética em Pesquisa com Seres Humanos da Universidade Estadual de Maringá, estando de acordo com a Resolução 196/96 - CNS.

Coleta das amostras. Amostras de $10 \mathrm{~mL}$ de sangue coagulado de 48 indivíduos, coletadas para realização do exame de sorologia de diagnóstico do dengue pela $15^{\text {a }}$ Regional de Saúde de Maringá, Paraná, no período de março a abril de 2007, foram utilizadas neste estudo. Essas amostras foram armazenadas em tubo do tipo Falcon de $15 \mathrm{~mL}$ em freezer $-80^{\circ} \mathrm{C}$ por pelo menos 3 dias. 0 descongelamento em banho-maria a $37^{\circ} \mathrm{C}$, por 10 minutos, foi seguido pelo banho de gelo, também, por 10 minutos. Após esse procedimento, as amostras foram homogeneizadas com pipeta Pasteur para se obter a dissolução máxima do coágulo ${ }^{1}$ e, novamente, congeladas até o uso.

Extração de DNA. Neste estudo, três metodologias de extração de DNA de buffy-coat ou sangue total foram avaliadas e modificadas para a obtenção de amostras de DNA de alta qualidade e alto rendimento a partir do sangue coagulado.

Método de extração por EZ-DNA ${ }^{\circledR}$ (Biological Industries, Kibbutz Beit Haemek, Israel). Após o descongelamento das amostras de sangue coaguladas, o DNA foi extraído, usando o kit de extração EZ-DNA ${ }^{\circledR}$, de acordo com as instruções do fabricante. Este kit contém o reagente Isotiocianato de Guanidina, um detergente usado para romper membranas celulares. 0 volume de $500 \mu \mathrm{L}$ de amostra tratada foi transferido para microtubos de 1,5mL, contendo 1,0mL de solução de RBCL (red blood cell lysis), composta por sacarose, triton $\mathrm{X}, \mathrm{MgCl}_{2} 6 \mathrm{H}_{2} \mathrm{O} 1 \mathrm{M}$, Tris
pH 7,51M e água ultrapura, homogeneizados em Vortex por 20 minutos, centrifugadas por 3 minutos a 6.280xg e o sobrenadante foi desprezado. Este procedimento foi repetido até a obtenção de um pellet o mais limpo possível. Após esta etapa, foi adicionado às amostras 1,0mL de solução de $\mathrm{RBC}^{\circledR}$ (red blood cell), com homogeneização em Vortex por 20 minutos e centrifugação por 3 minutos a 6.280xg. O sobrenadante foi descartado eforam adicionados $300 \mu \mathrm{L}$ de solução de EZ-DNA ${ }^{\circledR}$. As amostras permaneceram 7 dias em banho-maria a $56^{\circ} \mathrm{C}$ para a dissolução máxima do pellet. Esse tempo foi padronizado para as amostras coaguladas, devido à dificuldade na dissolução do coágulo. 0 DNA foi precipitado com $700 \mu \mathrm{L}$ de álcool absoluto gelado e os microtubos centrifugados por 1 minuto a $7.700 \mathrm{xg}$. O sobrenadante foi desprezado e $500 \mu \mathrm{L}$ de etanol $95 \mathrm{v} / \mathrm{v}$ foram adicionados às amostras. Novamente, os microtubos foram centrifugados por 1 minuto a 7.700xg, os quais, após o descarte do sobrenadante, foram mantidos abertos overnight (15-18h) para a secagem do álcool. A seguir, o DNA foi hidratado com 50 $\mu \mathrm{L}$ de água ultrapura e mantido a $-20^{\circ} \mathrm{C}$ até o momento do uso.

Extração de DNA pelo kit comercial de coluna. O DNA das amostras coaguladas e tratadas foi extraído utilizando-se o kit de extração por coluna NeoScience ${ }^{\circledR}$ (One Lambda Inc., San Diego, CA, USA), de acordo com as instruções do fabricante. Cerca de $500 \mu \mathrm{L}$ de amostra foram adicionados a microtubos de $1,5 \mathrm{~mL}$ contendo $20 \mu \mathrm{L}$ de proteinase $\mathrm{K}^{\circledast} 20 \mathrm{U} / \mathrm{mg}$ (Invitrogen, Carlsbad, CA, USA), para a eliminação inicial de proteínas. Em seguida, foram acrescentados $200 \mu \mathrm{L}$ de tampão 1.3 (tampão do kit NeoScience ${ }^{\circledR}$ ), para promover a lise das hemácias e lavagem da amostra, agitados por 1 minuto em Vortex e incubados por 15 minutos em banho-maria a $56^{\circ} \mathrm{C}$. Após um pulso em microcentrífuga, foram acrescentados $200 \mu \mathrm{L}$ de etanol absoluto gelado, seguido de 1 minuto de agitação em Vortex. Mais um pulso em microcentrífuga e as amostras foram transferidas para a coluna acoplada ao microtubo de $2 \mathrm{~mL}$. A seguir, foram centrifugados a 8.000xg por 1 minuto. Descartou-se o microtubo contendo o filtrado, a coluna foi transferida para um microtubo limpo e foram acrescentados 500 $\mathrm{L}$ do tampão 3.1 (tampão do kit NeoScience ${ }^{\circledast}$ ) no interior da coluna para lavagem da amostra e eliminação de proteínas e centrifugados a 8.000xg por 1 minuto. A seguir, o filtrado foi desprezado, a coluna transferida para um novo microtubo de $2 \mathrm{~mL}$ onde foram adicionados $700 \mu \mathrm{L}$ de tampão 4.1 (tampão do kit NeoScience ${ }^{\circledR}$ ) no interior da coluna, para a eliminação completa de impurezas da amostra. Foi realizada, a seguir, uma centrifugação de $14.000 x g$ por 3 minutos. Os microtubos contendo o filtrado foram descartados e as colunas transferidas para novos microtubos. A centrifugação com a coluna vazia foi realizada para retirar o excesso de tampão que permaneceu na coluna, a 14.000xg por 1 minuto. Esta coluna foi transferida para um microtubo de $1,5 \mathrm{~mL}$. A solução tampão de eluição 5.1 (tampão do kit NeoScience ${ }^{\circledR}$ ), pré-aquecida a $65^{\circ} \mathrm{C}$ $(40 \mu \mathrm{L})$, foi adicionada à coluna e os microtubos foram incubados por 5 minutos à temperatura ambiente. Após esse período, as amostras foram centrifugadas por 1 minuto a 14.000xg. Essa etapa foi repetida usando mais 30 $\mathrm{L}$ de tampão 5.1, para retirar o restante de DNA da coluna. Finalmente, a coluna foi descartada e o DNA obtido em $50 \mu \mathrm{L}$ de solução de hidratação (do kit NeoScience ${ }^{\circledR}$ ), mantido a $-20^{\circ} \mathrm{C}$ até o momento do uso. 
Extração de DNA por salting out. A técnica de salting out descrita por John e cols ${ }^{4}$ e modificada por Lahiri e Nurnberger ${ }^{5}$ foi adequada para a extração de DNA de amostras de sangue coaguladas. Cerca de $500 \mu \mathrm{L}$ da amostra de sangue coagulado e tratado para a dissolução do coágulo foram transferidos para microtubos de $1,5 \mathrm{~mL}$ e a eles foram acrescentados $1,0 \mathrm{~mL}$ de solução de RBCL (red blood cell lysis), composta por sacarose, triton $\mathrm{X}, \mathrm{MgCl}_{2} 6 \mathrm{H}_{2} \mathrm{O} 1 \mathrm{M}$, Tris $\mathrm{pH} 7,51 \mathrm{M}$ e água ultrapura, ao invés de $800 \mu \mathrm{L}$ mencionados no protocolo original, para a eliminação total de hemácias. Os microtubos foram agitados por 15 minutos, ao invés de apenas alguns segundos, e centrifugados por 2 minutos a $14.000 \mathrm{xg}$. 0 sobrenadante foi descartado e 0 processo se repetiu até a obtenção de um precipitado claro, sem vestígios de hemoglobina. Após esta etapa, foram adicionados às amostras $80 \mu \mathrm{L}$ de tampão de proteinase $\mathrm{K}^{\circledast}, 40 \mu \mathrm{L}$ de proteinase $\mathrm{K}^{\circledast}$ 20U/mg (Invitrogen, Carlsbad, CA, USA), 20 $\mu \mathrm{L}$ de SDS ${ }^{\circledast}$ (sulfato dodecil de sódio, Sigma Chemical Co, Steinheim, Germany) a $20 \mathrm{v} / \mathrm{v}$ e $240 \mu \mathrm{L}$ de água ultrapura, com homogeneização em Vortex por 15 segundos. Os microtubos foram incubados em banho-maria a $56^{\circ} \mathrm{C}$ por 40 minutos, com uma leve agitação em Vortex aos 20 minutos e, retirados após esse tempo, a fim de atingirem a temperatura ambiente. Foram adicionados $100 \mu \mathrm{L}$ de solução saturada de $\mathrm{NaCl}(6 \mathrm{M})$, com agitação em Vortex e centrifugação por 5 minutos a $14.000 \mathrm{xg}$. 0 sobrenadante foi transferido para outro microtubo contendo $100 \mu \mathrm{L}$ de $\mathrm{NaCl}$ (6M), o qual foi centrifugado por 5 minutos a $14.000 \mathrm{xg}$. 0 sobrenadante foi transferido para outro microtubo de $1,5 \mathrm{~mL}$, ao qual foram acrescentados $800 \mu \mathrm{L}$ de etanol absoluto gelado. 0 s tubos foram vertidos e invertidos, gentilmente, por várias vezes, para a precipitação do DNA e centrifugados a 14.000 xg por 2 minutos. 0 sobrenadante foi descartado e $500 \mu \mathrm{L}$ de etanol $70 \mathrm{v} / \mathrm{v}$ gelado, ao invés de $1 \mathrm{~mL}$, foram acrescentados às amostras, o que foi seguido de mais uma centrifugação de $14.000 \times \mathrm{xg}$ por 2 minutos. Depois do sobrenadante desprezado, os microtubos foram incubados overnight (15-18h) à temperatura ambiente para secagem do álcool, seguido de hidratação do DNA com $50 \mu \mathrm{L}$ de água ultrapura. As amostras foram mantidas a $-20^{\circ} \mathrm{C}$ até o momento do uso.

Genotipagem HLA (buman leukocyte antigens) por PCR-SSO (polymerase chain reaction-specific sequency of oligonucleotides). A avaliação da pureza do DNA foi realizada por meio da diluição das amostras com reagente fluorescente para a possível leitura na plataforma Qubit ${ }^{\circledR}$ (Invitrogen, Carlsbad, CA, USA). Após essa avaliação e ajuste da concentração, os genótipos HLA das amostras foram analisados pela técnica de $\mathrm{PCR}-\mathrm{SSO}^{\circledR}$ (polymerase chain reaction - specific sequence of oligonucleotides) (One Lambda Inc., Canoga Park, CA, USA) com tecnologia Luminex. Cada amostra de DNA, ajustada em $20 \mathrm{ng} / \mathrm{mL}$, foi adicionada a uma solução tampão (dNTP e $\mathrm{MgCl}_{2}$ ), juntamente com a enzima Taq DNA polimerase (5U/mL; Invitrogen ${ }^{\circledR}$, Carlsbad, CA, USA), seguindo os volumes recomendados pelo protocolo para amplificação dos loci. Após homogeneização desta solução, alíquotas foram dispensadas em tubos de polipropileno contendo os iniciadores específicos para os loci HLA-A, B, Cw, DRB1, DQA1 e DQB1. Os tubos foram, então, transferidos para o termociclador (Pelkin-Elmer 9600) para a amplificação dos loci, conforme recomendações do fabricante. Os fragmentos de DNA amplificados foram separados por eletroforese, em cuba micro SSP gel System ${ }^{\circledR}$ (MGS-B, One Lambda Inc., Canoga Park, CA, USA), em gel de agarose a 2,0v/v, a 150 volts por 10 minutos. A visualização das bandas foi realizada com Sybr Green ${ }^{\circledast}$ (Invitrogen, Carlsbad, CA, USA) em luz azul, e a interpretação dos resultados foi baseada na presença ou ausência do fragmento específico de DNA amplificado. As reações foram documentadas em fotografias (aparelho de fotografia Polaroid MP-4 Land). Os DNAs amplificados foram utilizados para a hibridização com pérolas ligadas a oligonucleotídeos específicos para estes alelos. A hibridização foi verificada por meio de um citômetro de fluxo LABScan ${ }^{\mathrm{TM}} 100$ flow analyzer. A seguir, os dados foram interpretados por meio do programa de computador HLA Visual $^{\text {th }}$ (One Lambda, Canoga Park, CA, USA, versão 2.2.0).

Genotipagem KIR (killer cell immunoglobulin-like receptors) por PCR-SSP (polymerase chain reactionsequence specific of primers). Após avaliação da pureza do DNA e ajuste da concentração pelo Qubit, as tipificações dos genes KIR foram realizadas pela técnica PCR-SSP (polymerase chain reaction-sequence specific of primers) padronizada in house (Rudnick CC, Guelsin GS, Marangon AV, FranceschiDS, Sell AM, Visentainer JE: no prelo). Cada amostra de DNA, ajustada em 10ng/ML, foi adicionada a uma solução de amplificação, previamente preparada, juntamente com a enzima Taq DNA polimerase $^{\circledast}$ (5U/ML; Invitrogen, Carlsbad, CA, USA), segundo os volumes recomendados pelo protocolo. Após homogeneização desta solução, alíquotas foram dispensadas em microtubos de polipropileno, contendo os iniciadores específicos para os genes KIR (Invitrogen, Carlsbad, CA, USA). Os microtubos foram, então, transferidos para o termociclador, para a amplificação dos genes. Os fragmentos de DNA amplificados foram separados por eletroforese, em cuba micro SSP gel System ${ }^{\circledR}$, em gel de agarose a 2,5v/v a 150 volts por 5 minutos. A visualização das bandas, quando expostas à luz azul, foi realizada pela coloração com Sybr green e a interpretação dos resultados foi baseada na presença ou ausência do fragmento específico de DNA amplificado. Para verificar a integridade da reação de PCR, foi utilizado um par de iniciadores como controle interno. As reações foram documentadas em fotografias (aparelho de fotografia Polaroide MP-4 Land).

\section{RESULTADOS}

As amostras extraídas pelo método EZ-DNA não se mostraram satisfatórias, uma vez que para a dissolução do botão de células, em solução, houve a necessidade de muitos dias de incubação em banho-maria (7 dias), levando assim à degradação do DNA, (dados não mostrados), além do dispendioso tempo necessário para a extração.

As amostras extraídas pelo kit comercial de coluna e por salting out foram, primeiramente, avaliadas com relação à concentração de DNA com o leitor Qubit (Tabela 1) e por eletroforese em gel de agarose pela análise das bandas (Figura 1). 
TABELA 1

Comparação entre as concentrações de DNAs obtidos por dois métodos de extração.

\begin{tabular}{|c|c|c|}
\hline & $\begin{array}{l}\text { Kit de coluna } \\
\text { NeoScience }{ }^{\circledR *}\end{array}$ & $\begin{array}{c}\text { Salting-out } \\
(\mathrm{ng} / \mu \mathrm{L})\end{array}$ \\
\hline Amostra & Concentração de DNA & \\
\hline DP-08 & $\mathrm{x}$ & 162,0 \\
\hline DP-10 & 13,5 & 78,3 \\
\hline DP-11 & $\mathrm{x}$ & 98,5 \\
\hline DP-66 & $\mathrm{x}$ & 131,0 \\
\hline DP-72 & $\mathrm{x}$ & 120,0 \\
\hline DP-73 & $\mathrm{x}$ & 190,0 \\
\hline DP-74 & $\mathrm{x}$ & 117,0 \\
\hline DP-78 & $\mathrm{x}$ & 75,1 \\
\hline DP-84 & 1,5 & 8,2 \\
\hline DP-88 & $\mathrm{x}$ & 341,0 \\
\hline DP-89 & 1,2 & 153,0 \\
\hline DP-90 & 1,7 & 164,0 \\
\hline DP-91 & $\mathrm{x}$ & 148,0 \\
\hline DP-92 & $\mathrm{x}$ & 243,0 \\
\hline DP-95 & $\mathrm{x}$ & 83,2 \\
\hline DP-99 & 1,4 & 148,0 \\
\hline DP-101 & 7,8 & 223,0 \\
\hline DP-105 & 5,8 & 149,0 \\
\hline DP-106 & $\mathrm{x}$ & 262,0 \\
\hline DP-111 & $\mathrm{x}$ & 378,0 \\
\hline DP-116 & $\mathrm{x}$ & 75,1 \\
\hline DP-123 & 1,5 & 190,0 \\
\hline DP-124 & $\mathrm{x}$ & 147,0 \\
\hline DP-149 & 6,3 & 220,0 \\
\hline DP-206 & 4,5 & 197,0 \\
\hline DP-180 & 5,3 & 840,0 \\
\hline DP-218 & 2,9 & 263,0 \\
\hline DP-225 & 3,6 & 287,0 \\
\hline DP-226 & $\mathrm{x}$ & 343,0 \\
\hline DC-34 & $\mathrm{x}$ & 28,0 \\
\hline DC-36 & $\mathrm{x}$ & 7,4 \\
\hline DC-40 & $\mathrm{x}$ & 2,6 \\
\hline DC-107 & $\mathrm{x}$ & 8,2 \\
\hline DC-164 & 3,4 & 105,0 \\
\hline DC-166 & $\mathrm{x}$ & 248,0 \\
\hline DC-167 & 2,9 & 333,0 \\
\hline DC-168 & $\mathrm{x}$ & 138,0 \\
\hline DC-169 & $\mathrm{x}$ & 229,0 \\
\hline DC-170 & 1,5 & 117,0 \\
\hline DC-171 & $\mathrm{x}$ & 302,0 \\
\hline DC-172 & $\mathrm{x}$ & 44,3 \\
\hline DC-174 & $\mathrm{X}$ & 120,0 \\
\hline DC-175 & $\mathrm{x}$ & 359,0 \\
\hline DC-176 & $\mathrm{x}$ & 197,0 \\
\hline DC-178 & $\mathrm{x}$ & 87,2 \\
\hline DC-179 & $\mathrm{X}$ & 400,0 \\
\hline DC-180 & $\mathrm{x}$ & 65,1 \\
\hline DC-181 & $\mathrm{X}$ & 131,0 \\
\hline
\end{tabular}

X: amostras cuja concentração foi menor que 1ng/ $\mu \mathrm{L}$, *0ne Lambda Inc. (San Diego, CA, USA). As concentrações foram avaliadas com o fluorômetro Qubit ${ }^{\circledR}$ (Invitrogen, Carlsbad, CA, USA).

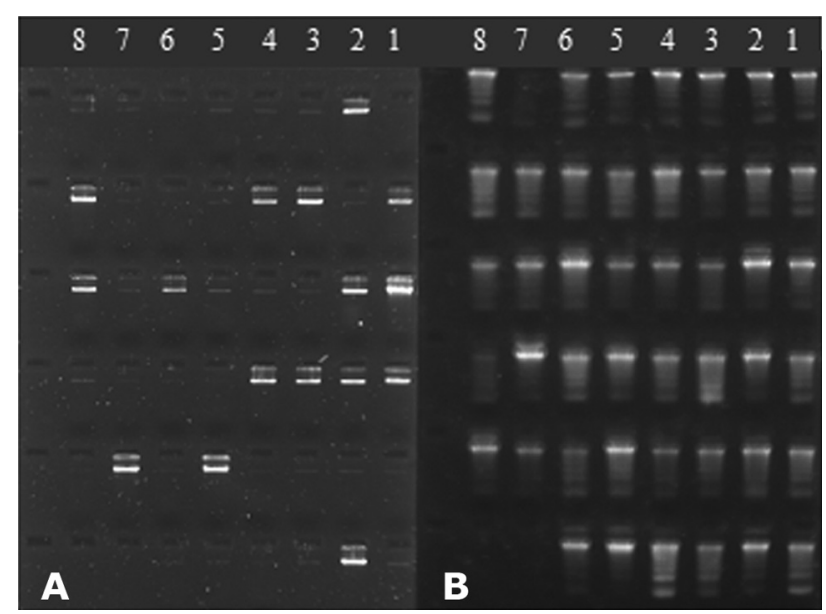

FIGURA 1

Análise da concentração ou integridade do DNA. A: Gel para avaliação das concentrações das amostras extraídas pelo kit comercial de coluna. B: Gel para avaliação das concentrações das amostras extraídas por salting-out. 0s números acima no gel representam as colunas onde cada amostra de DNA foi depositada para a corrida eletroforética.

Como não foi possível quantificar o DNA pelo Qubit, nas amostras extraídas pelo kit comercial de coluna, devido às baixas concentrações obtidas ( $<10 \mathrm{ng} / \mu \mathrm{L})$, as concentrações foram baseadas na espessura das bandas observadas no gel de agarose para a realização da amplificação do DNA pelas técnicas de PCR-SSO e PCR-SSP.

Os resultados das amplificações dos éxons 2 e 3 para os loci HLA classe I e éxon 3 para os loci HLA classe II, na técnica de PCR-SSO, com o DNA obtido de uma amostra de sangue pelas duas técnicas de extração, podem ser vistos nas Figuras 2 e 3.

Os resultados da identificação dos genes $K I R$, usando a técnica PCR-SSP, com o DNA obtido de uma amostra de sangue pelas duas técnicas de extração, podem ser vistos na Figura 4.

Os resultados das genotipagens $H L A$ e $K I R$, com todas as amostras extraídas pelo método de salting out, foram validados por metodologias de uso corrente no mercado (PCR-SSO Luminex).

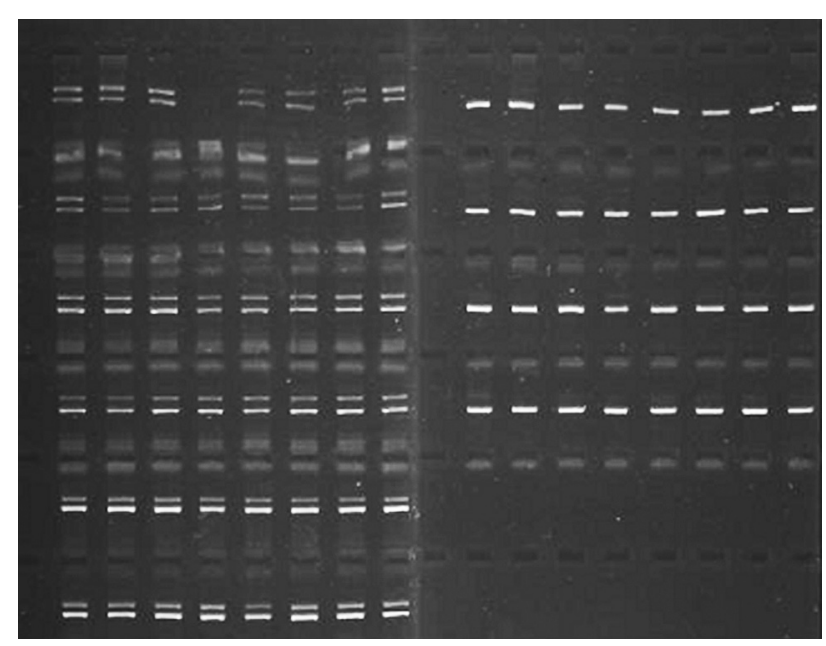

FIGURA 2

Amplificação dos loci HLA-A, B, Cw, DRB1 e DQA1/DQB1 de 16 amostras de DNAs extraídos pela técnica de salting-out. 1- locus HLA-A, éxons 2 e 3; 2-locus B, éxons 2 e 3; 3-locus $\mathrm{Cw}$, éxons 2 e 3; 4- locus DRB1, éxon 3; 5-locus DQA1/DQB1, éxon 3. Os números acima no gel representam as colunas onde cada amostra de DNA foi depositada para a corrida eletroforética. 


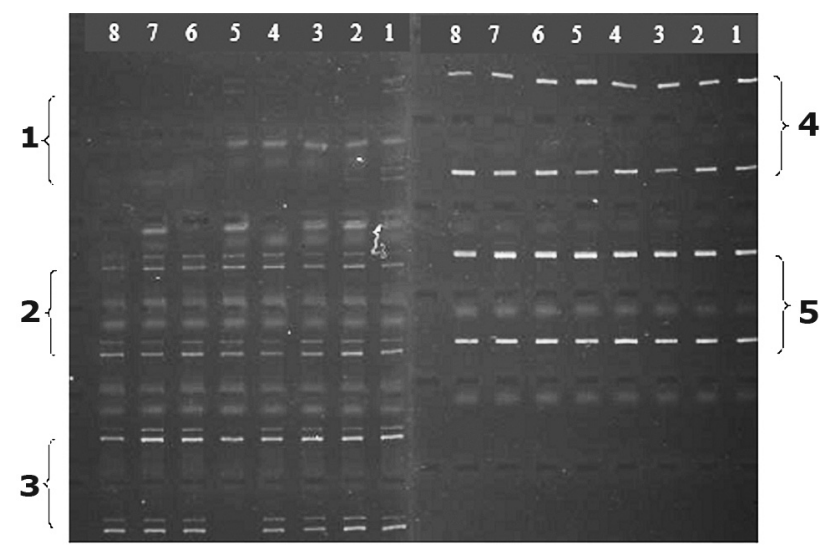

FIGURA 3

Amplificação dos loci HLA-A, B, Cw, DRB1 e DQA1/DQB1 de 16 amostras de DNA extraídos pelo kit de coluna (NeoScience, USA). 1- locus HLA-A, éxons 2 e 3; 2-locus B, éxons 2 e 3; 3-locus Cw, éxons 2 e 3; 4-locus DRB1, éxon 3; 5-locus DQA1/DQB1, éxon 3. Os números acima no gel representam as colunas onde cada amostra de DNA foi depositada para a corrida eletroforética.
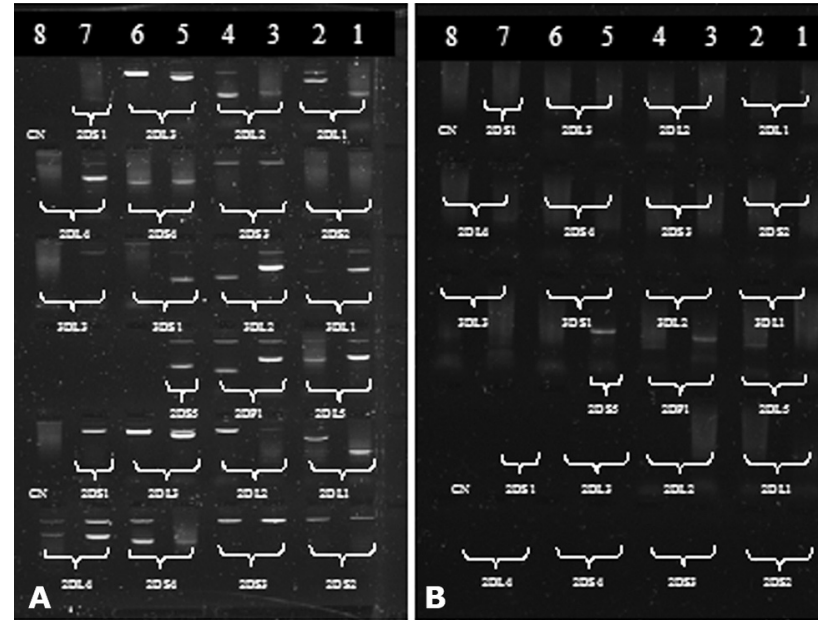

FIGURA 4

Genotipagem de 15 genes KIR por PCR-SSP de uma amostra de DNA. A: genotipagem KIR de DNA obtido por salting-out. Foram identificados como positivos os genes KIR 2DL1, 2DL2, 2DL3, 2DS1, 2DS2, 2DS3, 2DS4, 2DL4, 3DL1, 3DL2, 3DS1, 3DL3, 2DL5, 2DP1, 2DS5. B: Genotipagem KIR de DNA obtido por kit comercial de coluna. Os números acima no gel representam as colunas onde cada amostra de DNA foi depositada para a corrida eletroforética.

\section{DISCUSSÃo}

Independente da comparação, o método de extração de DNA por EZ-DNA não foi adequado quando o material biológico de origem foi o coágulo sanguíneo. As amostras de DNA obtidas não amplificaram por nenhuma das duas metodologias de PCR testadas e o procedimento foi demorado, uma vez que foi necessário um período de 5 a 7 dias, em banho-maria, a $56^{\circ} \mathrm{C}$, para a dissolução do botão de células nucleadas na solução de EZ, o que pode ter contribuído para a degradação do DNA.

Quando as mesmas amostras foram extraídas pelo kit comercial de coluna, algumas apresentaram bandas mais evidentes no gel de eletroforese do que outras (Figura 1A). Este kit de coluna é utilizado, normalmente, para extração de amostras de sangue total e proporciona amostras de DNA de alta qualidade; porém a concentração não é tão alta. Algumas amostras, obtidas por esse método, mesmo em baixa concentração, amplificaram pela PCR-SSO conforme mostrou a Figura 3, pois o DNA foi de qualidade muito boa. Mesmo assim, ocorreram muitas falhas, principalmente, nos loci $\mathrm{A} \mathrm{e} \mathrm{C}$, por estes exigirem concentrações um pouco maiores de DNA.

Os melhores resultados puderam ser vistos com a extração pelo método de salting out modificado, conforme visto na Figura 2. Todos os loci apresentaram ótimos padrões de amplificação que permitiram a posterior hibridização com sondas específicas para os alelos HLA.

Não foi possível a amplificação dos genes KIR pela técnica PCR-SSP, com as amostras obtidas pelo kit de coluna, pois ela exige uma concentração exata de $10 \mathrm{ng} / \mu \mathrm{L}$ e 0 equipamento Qubit não permitiu o ajuste adequado destas concentrações. Assim, o DNA extraído de amostras coaguladas por este kit de coluna não é conveniente para esta técnica de análise dos genes KIR. A melhor opção foi a adaptação da técnica caseira de salting out para amostras coaguladas. Ela se mostrou bastante eficiente, pois as concentrações foram altas e possíveis de serem quantificadas pelo Qubit. A qualidade do DNA também foi satisfatória, pois o DNA foi amplificado por ambas as técnicas de PCR avaliadas.

Em comparação com o método clássico de extração de DNA por salting out , algumas modificações foram necessárias devido ao estado de coagulação do sangue obtido. A amostra de sangue coagulado necessitou de um tratamento de choque térmico, para solubilização do coágulo, além de um volume maior de RCLB e de um tempo bem maior de agitação no Vortex, para a eliminação de todas as hemácias. Também foi possível a obtenção de DNA por precipitação usando metade do volume sugerido de etanol pela técnica original.

Por isso, pode-se concluir que a técnica de salting out é muito eficiente, simples e rápida para ser utilizada na extração de DNA de amostras de sangue humano coagulado por qualquer Laboratório de Biologia Molecular. Além disso, o DNA apresentou excelente qualidade e concentração adequada para amplificar os loci HLA e KIR pelas técnicas de biologia molecular PCR-SSO-Luminex e PCR-SSP made in house, respectivamente.

\section{AGRADECIMENTOS}

Agradecemos aos funcionários do Laboratório de Imunogenética da Universidade Estadual de Maringá, pelo apoio técnico e aqueles da Secretaria de Saúde de Maringá que colaboraram na obtenção das amostras de sangue.

\section{REFERÊNCIAS}

1. Adkins KK, Strom DA, Jacobson TE, Seemann CR, O`Brien DP, Heath EM. Utilizing Genomic DNA Purified From Clotted Blood Samples for Single Nucleotide Polymorphism Genotyping. Archives of Pathology and Laboratory Medicine 126:266-270, 2002 
2. Everson RB, Mass MJ, Gallagher JE, Musser C, Dalzell J. Extraction of DNA from Cryopreserved Clotted Human Blood. Biotechniques 15:18-20, 1993.

3. Garg UC, Hanson NQ, Tsai MY, Eckfeldt JH. Simple and Rapid Method for Extraction of DNA from fresh and Cryopreserved Clotted Human Blood. Clinical Chemistry 42:647-648, 1996.

4. John SW, Weitzner G, Rozen R, Scriver CR. A rapid procedure for extracting genomic DNA from leukocytes. Nucleic Acids Research 192: 408-408, 1991.
5. Lahiri DK, Nurnberger JI Jr. A rapid non-enzymatic method for the preparation of HMW DNA from blood for RFLP studies. Nucleic Acids Research 19: 5444-5444, 1991.

6. Zeillinger R, Schneeberger C, Speiser P, Kury F. A Simple Method for Isolation of DNA from Blood Clots Suited for use in PCR. Biotechniques 14:202-203, 1993. 